\title{
Familial adenomatous polyposis in a 5 year old child: a clinical, pathological, and molecular genetic study
}

\author{
S Distante, S Nasioulas, G R Somers, D J S Cameron, M A Young, S M Forrest, \\ R J M Gardner
}

\begin{abstract}
A girl aged 5 years 8 months presented with rectal bleeding; her father had had familial adenomatous polyposis (FAP) and a colectomy at the age of 23 . Endoscopy showed extensive polyposis and she had a colectomy. The proband and her father had the common codon 13095 bp deletion APC mutation. This mutation predisposes to early onset of FAP, and consideration needs to be given to having molecular testing of at risk members of these families done in childhood.

( $(\mathcal{}$ Med Genet 1996;33:157-160)
\end{abstract}

Key words: familial adenomatous polyposis; codon 1309 mutation.

The APC gene causing familial adenomatous polyposis (FAP) was mapped in $1987^{12}$ and cloned in $1991 .{ }^{34}$ Several mutations have been defined. ${ }^{5-10}$ Two common mutations, at codons 1061 and 1309 , account for about $20 \%$ and $9 \%$ of the total respectively. ${ }^{9}$ The latter mutation comprises a $5 \mathrm{bp}$ deletion extending from the last base of codon 1309 to the first base of codon 1311; for simplicity, we refer to this as the "codon 1309" APC mutation. Most APC mutations are frameshifts which produce a premature stop codon, with consequent truncation of the protein product. A genotypic-phenotypic correlation has been proposed, with longer truncated products (mutations in codon 1309 and beyond) associated with more severe and earlier onset disease and the presence of congenital hypertrophy of the retinal pigmented epithelium (CHRPE). ${ }^{11}$ Shorter truncated products cause a milder disease, and a very short truncated product leads to "attenuated polyposis". ${ }^{1213}$ We describe a family with the codon 1309 mutation, with onset in young adulthood and young childhood respectively in the father and daughter, and we review the molecular genetics of childhood polyposis.

\section{Case report}

The proband presented initially at the age of 5 years 8 months with rectal bleeding and frequent stools. The clinical pattern suggested bacterial infection, but no recognised pathogens were isolated. Her symptoms settled within a few days, but rectal bleeding recurred one month later in the absence of other symptoms. She had no previous gastrointestinal or extra-intestinal symptoms or signs. Colonoscopy showed hundreds of sessile polyps of varying sizes, up to about $10 \mathrm{~mm}$ in diameter. There was no unequivocal observation of a polyp in the distal ileum. On gastroduodenoscopy there were two small sessile polyps seen in the second part of the duodenum. Follow through barium contrast $x$ rays did not show any additional polyps in the small intestine. She underwent a total proctocolectomy and ileal pull through procedure with a temporary loop ileostomy which was subsequently closed.

The resected colon contained innumerable polyps, measuring up to $9 \mathrm{~mm}$ in diameter. Most were sessile, although a small number were slightly pedunculated. There were occasional small areas of ulceration. The rectum contained relatively few polyps, with normal mucosa in between. Histology of both colonic and duodenal polyps showed many adenomatous polyps with no extension beyond the muscularis mucosae.

Subsequent endoscopic surveillance at the age of 6 years 10 months showed small sessile polyps in the stomach (2), pylorus (1), second part of the duodenum (2), and first part of the jejunum (1), all too small to be removed endoscopically; there were none in the terminal ileum.

The girl's father, himself an only child, was diagnosed with FAP at the age of 23 years, and he had total colectomy with permanent ileostomy. We had planned an ophthalmological assessment as part of the family study; however, he became ill with an extremely aggressive pulmonary infiltrative condition and died within a few weeks, at the age of 45 , the diagnosis being lymphoma. His father was said to have been diagnosed with polyposis in his twenties; he had had a permanent ileostomy and died at 51 years of an apparently unrelated cause. The girl's paternal great grandfather was said to have died of bowel cancer in his eighties. 


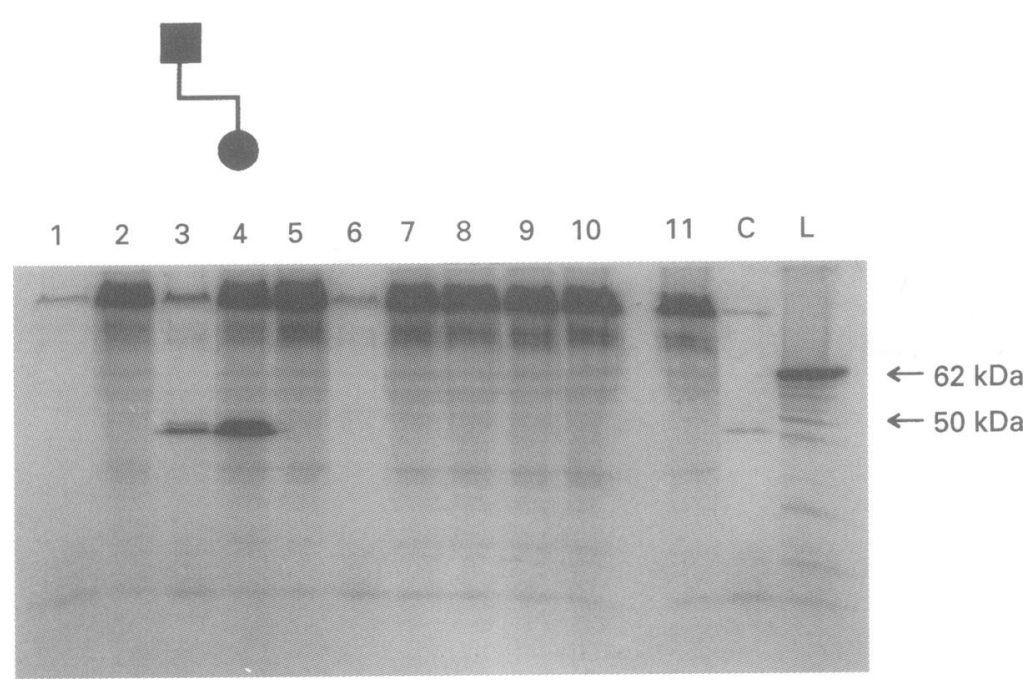

Protein products in the father (lane 3) and child (lane 4) from the in vitro translation assay to detect protein truncation. Lane $C$ is a known codon 1309 mutation. Lanes 1-2 and 5-11 are other FAP cases. $L=$ size ladder.

No extracolonic features were anecdotally reported in the father, grandfather, or great grandfather. Her older brother underwent gastroduodenoscopy and ileocolonoscopy aged 12 years 4 months; no polyps or other abnormalities were seen.

\section{Molecular studies}

Primers used for amplification of a fragment of exon 15 ("fragment 3", comprising codons 1029-1701) were those designed by van der Luijt et al. ${ }^{14}$ Polymerase chain reaction (PCR) was done under standard conditions. The final concentration of magnesium chloride was $1.5 \mathrm{mmol} / 1 \mathrm{MgCl}_{2}$ and the annealing temperature $56^{\circ} \mathrm{C}$. PCR conditions were denaturation at $95^{\circ} \mathrm{C}$ for one minute, annealing temperature for one minute, and extension at $72^{\circ} \mathrm{C}$ for two minutes, for a total of 40 cycles. The protein truncation test (PTT) was based on the method of Roest et al ${ }^{15}$ using the TnT T7 reticulocyte system (Promega). Incorporation of ${ }^{35} \mathrm{~S}$ methionine was used to detect the translation protein products. Separation was done on a $14 \%$ SDS-polyacrylamide gel which was fixed and then dried and exposed to $x$ ray film.

Testing of "fragment 3" by the protein truncation test (PTT) showed a truncated protein of around $50 \mathrm{kDa}$ in size, in the samples from both the child and her father. A patient with a known codon 1309 mutation was used as a control and gave a truncated protein product of the same size (figure). The region encompassing the mutation was amplified from genomic DNA using the primers of Ando et $a l^{16}$, and the child and father showed the $5 \mathrm{bp}$ deletion (results not shown).

\section{Discussion}

It is rare for familial adenomatous polyposis to present in childhood. Polyps may begin to form at an early age, ${ }^{17}$ but sufficient growth to be symptomatic or to warrant consideration of prophylactic colectomy does not usually occur until late adolescence or adulthood. While diagnosis by surveillance colonoscopy owing to positive family history is being increasingly described, ${ }^{18}$ actual clinical presentation in the paediatric age group is very rare. (It is necessary to draw a distinction between FAP in a juvenile and the separate entity of juvenile polyposis. ${ }^{19}$ The coexistence of juvenile and adenomatous polyps has been the subject of several recent reviews $^{20-23}$ and presents a diagnostic challenge.)

Abramson ${ }^{17}$ published a remarkable review of childhood polyposis up to the 1960s. He was able to find two reports from the 1890s and 32 from this century, presenting from infancy through to 13 years of age. His pathological description of "multiple polyposis" with family history translates into the more modern term of FAP, and he did account for the distinction from other types of polyp. Peck et al, ${ }^{24}$ in 1972, recorded a total of 11 persons with FAP aged 16 years and under who had bowel cancer; six of these were children aged 12 and under. Possibly the youngest ever reported case is that of LeFevre and Jacques ${ }^{25}$ in 1951, a 4 month old infant with symptomatic prolapsing polyposis which led to death from intussusception and gangrene.

Thereafter, there have not been many reports of FAP in childhood. Bülow ${ }^{26}$ reviewed the Danish Polyposis Register up to 1982, and recorded an age range for onset of bowel symptoms of 2 to 73 years. Chow et al ${ }^{19}$ recorded the case of a 12 year old presenting with scalp epidermoid cysts and with multiple polyps, whose sibs (aged 11 and 13) and mother also had Gardner's syndrome. Ruttenberg et $a l^{27}$ reported an 8 year old with FAP presenting with acute abdominal pain in whom colonoscopy showed over 100 polyps, and one large pedunculated polyp $(3.5 \mathrm{~cm})$ had a significant degree of dysplasia.

Since the discovery of the APC gene, it has been recognised that patients with the codon 1309 mutation, or with mutations $3^{\prime}$ of this point, generally have a more severe disease phenotype (defined as the presence of thousands of polyps rather than hundreds, age of onset before 12 years, or advanced neoplastic disease before 30 years). ${ }^{11}$ In the small number of childhood cases (12 years of age and under) so far reported having had mutational analysis, 10 have had the codon 1309 mutation, ${ }^{11} 2829$ and five have had mutations more $3^{\prime}$ in the gene, within codons 1445 to $1578 .^{30}$ With respect to the codon 1309 mutation, Gayther et al ${ }^{11}$ list two 7 year olds, a 9 year old, and a 12 year old presenting symptomatically or with cancer. The two children in the report of Caspari et $a l^{28}$ presented with intestinal bleeding at the ages of 4 and 6 years, and had subtotal colectomies at the ages of 7 and 8 years, respectively. Presciuttini et $a l^{29}$ recorded an 8 year old and a 10 year old in one family with the codon 1309 mutation, and an 8 year old and a 13 year old in another; they make the case that anticipation characterises the transmission of this and some other APC alleles. The child we report here with the codon 1309 
mutation presented at the age of 5 years 8 months, and had a severe degree of colonic polyposis and upper gastrointestinal tract involvement; her family history is not inconsistent with the possibility of anticipation.

Another mutation associated with early onset is the $13 \mathrm{bp}$ deletion from nucleotides 25042516 causing a stop codon at position 835, recorded in a 14 year old..$^{29}$ Presciuttini et al, ${ }^{29}$ noting the more $5^{\prime}$ location of this mutation, proposed a revision of the model of a "linear" molecular-clinical correlation, and suggest that mutations at particular critical points, rather than simply according to distance along the gene, cause more aggressive disease; the case of Eccles $e t ~ a l,{ }^{31}$ a girl who died of colon cancer aged 16 years and had a de novo mutation at codon 1179, provides further illustration. Caspari et $a l^{30}$ expanded on this theme, and showed that persons with mutations beyond codon 1444 almost always have desmoid tumours, osteomas, epidermoid cysts, and polyps of the upper gastrointestinal tract, but no CHRPEs. In fact, their only cases with beyond 1444 mutations who did not have desmoids were children (ages 4,5 , and 10 years); one 14 year old had a desmoid tumour present since birth. Some Turcot's syndrome (colorectal polyposis plus primary brain tumour) results from APC mutation, and with this entity, in contrast, the coexistence of brain tumour seems unrelated to the site of mutation. ${ }^{32}$

Given the molecular-clinical correlation, is it appropriate to provide specifically tailored advice to families with "early onset mutations"? While normal practice may be to offer testing to young persons at risk for FAP mutations during early teenage (the time at which colonoscopy would otherwise have been proposed), in those in whose family the mutation is at codon 835,1309 , or beyond 1444 , or is otherwise a known early onset mutation, a younger age may be advisable. Our patient's older brother, aged 12, had already had normal endoscopy, as noted above, and our plan was to make mutation testing available to him, using a modified version of the protocol we apply to adult predictive testing. In preliminary discussion, he appeared to have a good understanding of the issues. His father's recent death from a presumed unrelated malignancy led us to defer the matter. The British Clinical Genetics Society has addressed the question of predictive testing in children, taking cognisance of such matters as the child's future autonomy and confidentiality. ${ }^{33}$ Of 49 geneticists questioned, $16(33 \%)$ would not test a 5 year old at risk for FAP whose parents wanted to know the child's genetic status. Clayton ${ }^{34}$ commented that there is the possibility of conflict with parents, as physicians come increasingly to act as advocates for what they see as the child's interests, but notes further that "children are generally ill-served if their parents feel they have not been listened to"; and the Genetic Interest Group in the UK has enunciated the following principle: "After suitable counselling, parents have the right to make an informed choice about whether or not to have their children tested for carrier status. Ideally, children should only be tested when of an age to be involved in the decision". ${ }^{35}$ In the specific case of an "early onset FAP mutation", we propose that a more liberal view may be warranted, both in response to justifiable parental concern, and for medical management of the child's condition, because we do not at present know the risk for progression to malignant change before adolescence.

\section{Note added in proof}

The brother, now 13 years old, did present for predictive testing. We were impressed with his intelligent and articulate appreciation of the issues. He did not have his father's APC mutation.

We thank Dr C W Chow for his advice on the pathology. S Distante was a visiting medical student from the University of Aberdeen.

1 Bodmer WF, Bailey CJ, Bodmer J, et al, Localisation of the gene for familial polyposis on chromosome 5. Nature 1987 328:614-16.

2 Leppert M, Dobbs M, Scambler P, et al. The gene for familial polyposis coli maps to the long arm of chromosome 5. Science 1987;238:1411-13.

3 Nishisho I, Nakamura Y, Miyoshi Y, et al. Mutations of chromosome 5q21 genes in FAP and colorectal cancer chromosome 5q21 genes in FAP

4 Groden J, Thliveris A, Samowitz W, et al. Identification and characterization of the familial adenomatous polyposis coli gene. Cell 1991;66:589-600.

5 Cottrell S, Bicknell D, Kaklamanis L, Bodmer WF. Molecular analysis of APC mutations in familial adenomatous polyposis and sporadic colon carcinomas. Lancet 1992, 340:626-30.

6 Fodde R, van der Luijt R, Wijnen J, et al. Eight nove inactivating germ line mutations at the APC gene identified by denaturing gradient gel electrophoresis. Genomics 1992 13:1162-8.

7 Mandl M, Friedl W, Paffenholz R, et al. Frequency of common and novel inactivating APC mutations in 202 families with familial adenomatous polyposis. Hum Molec Genet 1994;3:181-4.

8 Miyoshi Y, Ando H, Nagase H, et al. Germ-line mutations of the APC gene in familial adenomatous polyposis of the APC gene in familial adenomatous polypo

9 Nagase H, Nakamura Y. Mutations of the APC (adenomatous polyposis coli) gene. Hum Mutat 1993;2:42534.

10 Olschwang S, Laurent-Puig P, Groden J, et al. Germ-line mutations in the first 14 exons of the adenomatous polyposis coli (APC) gene. Am f Hum Genet 1993;52:273-9.

11 Gayther SA, Wells D, SenGupta SB, et al. Regionally clustered APC mutations are associated with a severe phenotype and occur at a high frequency in new mutation cases of adenomatous polyposis coli. Hum Molec Genet 1994;3:53-6.

12 Spirio L, Olschwang S, Groden J, et al. Alleles of the APC gene: an attenuated form of familial polyposis. Cell 1993; 75:951-7.

13 Smith-Ravin J, Pack K, Hodgson S, Tay SKS, Phillips R, Bodmer W. APC mutation associated with late onset of familial adenomatous polyposis. $₹$ Med Genet $1994 ; 31$ : familial ade.

14 Van der Luijt $\mathrm{R}$, Khan PM, Vasen $\mathrm{H}$, et al. Rapid detection of translation-terminating mutations at the adenomatous polyposis coli (APC) gene by direct protein truncation test. Genomics 1994;20:1-4.

15 Roest PAM, Roberts RG, Sugino S, van Ommen GJB den Dunnen JT. Protein truncation test (PTT) for rapid detection of translation-terminating mutations. Hum Molec Genet 1993;2:1719-21.

16 Ando $H$, Miyoshi Y, Nagase H, Baba S, Nakamura Y Detection of 12 germ-line mutations in the adenomatous polyposis coli gene by polymerase chain reaction. enterology 1993;104:989-93.

17 Abramson DJ. Multiple polyposis in children: a review and a report of a case in a 6-year-old child who had associated a report of a case in a 6-year-old child who had as

18 Burn J, Chapman PD, Eastham EJ. Familial adenomatous polyposis. Arch Dis Child 1994;71:103-5.

19 Chow CW, Taylor RG, Stokes KB, Smith AL. Gastrointestinal polyposis in infancy and childhood. Pediatr Surg Int 1988;4:27-34.

20 Veale AMO. The polyposes. In: Emery AEH, Rimoin DL eds. Principles and practice of medical genetics. 2nd ed. Edinburgh: Churchill Livingstone, 1990:1125-33.

21 Giardiello FM, Hamilton SR, Kern SE, et al. Colorectal neoplasia in juvenile polyposis or juvenile polyps. Arch Dis Child 1991;66:971-5.

22 Heiss KF, Schaffner D, Ricketts RR, Winn K. Malignant risk in juvenile polyposis coli: increasing documentation 
in the pediatric age group. $\mathcal{P}$ Pediatr Surg 1993;28:1188-93. 23 O'Riordain DS, O'Dwyer PJ, Cullen AF, McDermott EW, Murphy JJ. Familial juvenile polyposis coli and colorecta cancer. Cancer 1991;68:889-92.

24 Peck DA, Watanabe KS, Trueblood HW. Familial polyposis in children. Dis Colon Rectum 1972;15:23-9.

25 LeFevre HW, Jacques TF. Multiple polyposis in an infant of four months. Am $\mathcal{f}$ Surg 1951;81:90.

26 Bülow S. Clinical features in familial polyposis coli. Results of the Danish polyposis register. Dis Colon Rectum 1986; 29:102-7.

27 Ruttenberg D, Elliot MS, Bolding E. Severe colonic dysplasia in a child with familial adenomatous polyposis. Int plasia in a child with familial

28 Caspari R, Friedl W, Mandl M, et al. Familial adenomatous polyposis: mutation at codon 1309 and early onset of colon cancer. Lancet 1994;343:629-32.

29 Presciuttini S, Varesco L, Sala P, et al. Age of onset in familial adenomatous polyposis: heterogeneity within families and among APC mutations. Ann Hum Genet 1994;58:331-42. 30 Caspari R, Olschwang S, Friedl W, et al. Familial adenomatous polyposis: desmoid tumours and lack of ophthalmic lesions (CHRPE) associated with APC mutation beyond codon 1444. Hum Molec Genet 1995;4:337-40.

31 Eccles DM, Bunyan DJ, Needell J, Thompson M. Colon cancer in a 16-year-old girl. Lancet 1995;345:1643.

32 Hamilton SR, Liu B, Parsons RE, et al. The molecular basis of Turcot's syndrome. N Engl ₹ Med 1995;332:839-47.

33 Clarke A, Fielding D, Kerzin-Storrar L, et al. The genetic testing of children. Report of a working party of the testing of children. Report of a working party of the 785-97.

34 Clayton EW. Removing the shadow of the law from the debate about genetic testing of children. Am f Med Genet 1995;57:630-34

35 Dalby S. GIG response to the UK Clinical Genetics Society report "The genetic testing of children". $\mathcal{F}$ Med Genet 1995;32:490-4. 